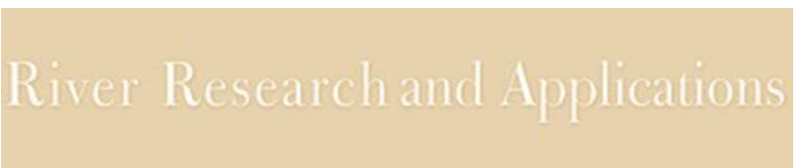

\title{
The magnitude and significance of sediment oxygen demand in gravel spawning beds for the incubation of salmonid embryos.
}

\begin{tabular}{|r|l|}
\hline Journal: & River Research and Applications \\
\hline Manuscript ID & RRA-17-0007.R1 \\
\hline Wiley - Manuscript type: & Special Issue Paper \\
\hline Complete List of Authors: & $\begin{array}{l}\text { Sear, David; University of Southampton, Geography \& Environment } \\
\text { Pattison, Ian; Loughborough University, Civil \& Building Engineering } \\
\text { Collins, Adrian; Rothamsted Research - North Wyke, Sustainable Soils and } \\
\text { Grassland Systems } \\
\text { Jones, John; Queen Mary University of London, School of Biological and } \\
\text { Chemical Sciences; Queen Mary University of London, School of Biological } \\
\text { and Chemical Sciences } \\
\text { Naden, Pam; Centre of Ecology and Hydrology, - } \\
\text { Smallman, David; University of Southampton, Civil Engineering \& } \\
\text { Environment }\end{array}$ \\
\hline Keywords: & $\begin{array}{l}\text { Organic Matter, Sediment Oxygen Demand, Modelling, Sediment Oxygen } \\
\text { Consumption, Salmon Spawning Habitat }\end{array}$ \\
\hline
\end{tabular}




\section{Abstract}

Globally, salmon populations are under pressure and in those where numbers are severely depleted, density independent factors such as the accumulation of fine sediment and subsequent mortality of incubating embryos are critical factors in their conservation. Whilst progress has been made in identifying the processes by which fine sediment can lead to embryo mortality, this has focussed on the physical blockage of gravel pores. This paper presents new knowledge on the role of sediment-associated organic matter (OM) in controlling the supply of dissolved oxygen to incubating salmon embryos within gravel river beds. We report a new approach to the measurement of Sediment Oxygen Demand (SOD) from interstitial sediments accumulated within salmon redds, and demonstrate this across a range of salmon river types. The effects of varying SOD on dissolved oxygen supply to incubating salmon embryos are quantified for the first time, using the physicallybased Sediment Intrusion and Dissolved Oxygen (SIDO-UK) model. The results reveal the importance of the mass of accumulating sediment, and sediment consumption rates (SOC) which constitute the overall SOD over time for a particular sediment sample. Higher SOC result in reductions in dissolved oxygen that are deleterious to salmonids; however, these are subordinate to the effects of sediment mass. Larger quantities of sediment accumulating within the redd not only create a higher SOD, but also physically block the pores within the gravels, leading to a more drastic decline in oxygen supply through the combined effects of reduced seepage velocity and dissolved oxygen concentration. We seek to generalise the results by exploring the influence of catchment characteristics on field measures of SOD and SOC. This work makes a significant and novel contribution to improving our fundamental understanding of hyporheic processes within salmonid spawning gravels whilst providing resource managers with evidence of the deleterious effects of sediment-associated OM on salmon recruitment.

Key Words: Organic matter, Sediment Oxygen Demand (SOD), Sediment Oxygen Consumption (SOC), Modelling, Salmon spawning habitat.

\section{Introduction}

Global concerns over the decline of migratory salmonid populations have focussed on the recruitment during freshwater life stages. In North America, the declines of 
both Atlantic and Pacific salmon runs since human occupation has resulted in the extirpation of salmon from river catchments and driven a multi-billion US\$ industry in habitat restoration (Palmer et al., 2005; Sear and DeVries, 2008). In Europe, a similar pattern has been observed, resulting in specific legislation to protect and restore the habitat of Atlantic salmon (WWF, 2001; Sear, 2010). Scientists have concluded that improved understanding of the factors leading to salmonid decline is essential to establishing a sustainable resource (Beechie et al., 2010). There is a consensus based on a growing evidence base, that contributory factors include the simplification, modification and decline in the quality of freshwater habitats (Parrish et al., 1998; WWF, 2001; Sear, 2010). These identify embryo development within the river bed as the most critical life stage, during which mortality is typically high (Quinn, 2005). Key to understanding the reasons for high mortality and thus improved resource management lies in being able to identify those factors that control the development of the incubating embryo (Quinn 2005). Increasingly, this requires improved understanding of the bio-geochemical processes that affect the supply of oxygen to incubating embryos within the stream bed (Greig et al., 2007a).

Critically, although not exclusively, embryo mortality is dependent on the supply of dissolved oxygen (DO), essential macro- and micronutrients, and the removal of potentially toxic metabolic by-products via the water within the hyporheic zone (Chapman, 1988; Greig et al., 2007a). The most frequent factor cited as contributing to the decline in productivity of spawning habitat is the intrusion and accumulation of fine sediment and associated OM into salmonid redds (Sear et al., 2008). Hypotheses to explain these findings are based on the theory that to support the oxygen consumption of incubating embryos, the rate of oxygen supply to the boundary layer surrounding the egg, must be greater than the rate of consumption of oxygen within the egg (Daykin 1965; Greig et al., 2007a). Based on this theory, the effect of fine sediment accumulation within the spawning gravels post redd cutting can be articulated in four hypotheses: (1) sediment blocks interstitial pores reducing flow velocities and hence the rate of supply of oxygen (Stuart, 1953; Olsson and Persson, 1988; Sear et al., 2008); (2) sediment blocks the micropores on the surface of eggs resulting in a reduction in the uptake of oxygen by incubating embryos (Greig et al., 2005a); (3) sediment-associated pollutants are toxic to fish eggs (Ballantine et al., 2009), and; (4) sediment consumes oxygen, through the oxidation of organic 
matter (OM) and nitrogenous compounds, reducing concentrations in the egg zone (Chevalier et al., 1984; Greig et al., 2005b). Sediment oxygen demand in gravel-bed rivers (SOD), has to date been poorly quantified (only 2 reported field measurements - Theurer and Theurer (1986); Greig (2004)) yet has been identified by Malcolm et al. (2008) as a key area for further research. Moreover, the magnitude of the effect of SOD in reducing the oxygen available to support embryo development has yet to be quantified. This paper addresses these critical gaps by; 1) using a novel methodology to provide measurements of the SOD of fine sediment accumulated within salmon spawning redds from a range of different river catchments (e.g., groundwater dominated, large lowland gravel-bed pool-riffle rivers, steep upland pool-rifle streams), and; 2), using a numerical model of the oxygen budget within a spawning redd to quantify the effect of SOD on the supply of oxygen to Atlantic salmon embryos. In addition, the aims of the paper are threefold; to provide new field data on the SOD and SOC of fine sediments intruded into salmon redds; second, to extend the field data using a physically-based oxygen model to explore the magnitude of the impact of varying SOD and SOC on oxygen supply to incubating salmonids, and; thirdly, to generalise the field data by evaluating the relationship between measured SOD and SOC and wider catchment characteristics.

\section{Sediment Oxygen Demand}

SOD is the loss of dissolved oxygen from the water column through biological and chemical oxidation processes occurring within the sediment (Hondzo and Steinberger, 2008). SOD is often said to be composed of three elements: (1) Biological Oxygen Demand (BOD); (2) Nitrogen Oxygen Demand (NOD), and; (3) Chemical Oxygen Demand (COD). BOD is the decomposition of OM which accumulates in the subsurface gravels by micro-organisms. This process occurs by carbon oxidation (equation 1) and is thought to occur at the sediment-water interface where the sediment is coated with a microbial biofilm (Lundkvist et al., 2007). The rate of this process is believed to peak between 10 and 14 days and is shown by line (a) in Figure 1.

$\mathrm{CH}_{2} \mathrm{O}+\mathrm{O}_{2} \rightarrow \mathrm{CO}_{2}+\mathrm{H}_{2} \mathrm{O}$ Aerobic Respiration (carbon oxidation)

NOD is the oxidation of nitrogen containing compounds, such as ammonium (often found in fertilisers) and inorganic sediments. The process of nitrification converts 
ammonium to nitrite (equation 2) followed by nitrate (equation 3) through oxidation by nitrifying bacteria (Gaudy and Gaudy, 1980). This process is delayed and usually peaks on about day 25 (Chevalier et al., 1988) (line b Figure 1).

$2 \mathrm{NH}_{4}^{+}+3 \mathrm{O}_{2} \rightarrow \mathrm{NO}_{2}^{-}+4 \mathrm{H}^{+}+2 \mathrm{H}_{2} \mathrm{O}$

$2 \mathrm{NO}_{2}^{-}+\mathrm{O}_{2} \rightarrow 2 \mathrm{NO}_{3}^{2-}$

COD as defined in this instance, in contrast to the typical wastewater description, accounts for the oxidation of only the inorganic substances, e.g. iron sulphite. These are often rapidly oxidised, but are typically a minor contribution to total SOD, except in rivers with high industrial effluent discharges (Cox, 2003).

There are two separate processes that consume oxygen within the egg zone of a salmon red: 1) the decay of sediment-associated OM transported into the pores between framework gravels, and; 2) the respiration of salmon eggs and, after hatch, salmon alevin (Theurer and Theurer, 1986).

The dominant controls on SOC are: (1) temperature; (2) intra-gravel flow velocity, and; (3) organic content both in the solid matrix and entrained in the pore water. The rates of biological processes e.g. respiration, are temperature dependent (Di Torro, 2001). It is widely accepted that $a 10^{\circ} \mathrm{C}$ rise in temperature results in a doubling of SOC (McDonnel and Hall, 1969). SOC increases linearly with velocity at speeds less than $10,800 \mathrm{~cm}$ hour $^{-1}$ (such as found within the pores of redds) (Nakamura and Stefan, 1994; Josium and Stefan, 1999), while at higher velocities, SOC is independent.

SOC is also reliant upon the types of OM. Labile carbon is highly bioavailable and decays rapidly, while refractory carbon is more resistant to decay (Otten et al., 1992; Cole and Wells, 2008). Furthermore, particulate and dissolved OM (that which passes through a $0.45 \mu \mathrm{m}$ filter) decay at different rates (Jewell and McCarty, 1971; Yoshimura et al., 2008). Particle size is also important, as this influences the surface area subject to decomposition (House, 2003). SOC rate is independent of the dissolved oxygen concentration over $2 \mathrm{mg} \mathrm{L}^{-1}$ (Edwards and Rolley 1965; Chevalier and Murphy 1985). 
Along, with the controls on SOD being complex, the other reason why few values exist for SOD is that there is currently no standard method for measuring it (Miskewitz et al., 2010). SOD can either be assessed in-situ in the field or from samples taken and analysed in laboratories (Table 1). This makes the comparison between different studies difficult (Chau, 2002). For example, Patterson et al. (1975) found that values for the same sediment differed by 10 times between field and laboratory measurements. It is thought that in-situ measurements are favoured, as they most accurately represent the natural ambient conditions and errors are not introduced by transferring to the laboratory. However, field measurement within spawning gravel substrates is extremely difficult, especially in terms of the amount of time that experiments can proceed. Typically benthic SOD chambers are deployed on the bed surface for period of a few minutes, and the SOD extrapolated from this data (Doyle and Lynch, 2005). The only reported measurements from within salmonid redds involved the use of freeze coring to recover bulk sediments, followed by laboratory incubation of the previously separated fine sediments within an incubator (Chevalier and Murphy, 1985; Theurer and Theurer, 1986; Greig 2004).

\section{Modelling SOD in a salmon redd}

The SIDO (Alonso et al., 1996) and SIDO-UK models (Carling et al., 2003; Sear 2010; Pattison et al., in review) are physically-based and deterministic, representing the 1D channel hydraulics through the St Venant equations, sediment transport with the Einstein-Brown bedload transport equation and suspended sediment transport via the Rouse number (see Alonso et al.,1996 for a detailed review). Sediment accumulation within the salmon redd is simulated on a daily time step in relation to the near bed concentration of suspended sediment. Sand, silt and clay sized particles are deposited within each cell of the egg zone in a salmon redd (for full details of the process see Alonso et al., 1996). The flow of water and oxygen through the redd are represented using the Darcy equation and through the process of convection. SOD is related to the amount of silt and clay that has accumulated within a salmon redd according to the model developed by Theurer and Theurer (1986):

$$
\Delta S O D=S O D \Delta M_{f}
$$


Where $\triangle S O D$ is the sediment oxygen demand transported through, or accumulated in, the redd $(\mathrm{mg} / \mathrm{L}), S O D$ is the ultimate SOD (defined by the SOD value measured over a 20-day period) in $\mathrm{mgO}_{2} \mathrm{~g}^{-1}$ dry wt. sediment, and $\mathrm{M}_{\mathrm{f}}$ is the mass of fines (silt and clay) added to the redd ( $\mathrm{g} / \mathrm{L})$.

SOC follows a classic decay pattern over time, expressed by the following relationship:

$$
\operatorname{SOC}=\operatorname{SOD}\left(1-e^{-k t}\right)
$$

where $k$ is the deoxygenation constant $\left(\right.$ day $\left.^{-1}\right)$ and $t$ is the time (day) (Theurer and Theurer, 1986).

The SOD remaining at the end of each day is equal to the amount at the beginning of the day plus the amount added during the day, less the amount consumed during the day, according to:

$$
\mathrm{SOD}_{\mathrm{i}}=\mathrm{SOD}_{, j-1}+\mathrm{SOC}-\triangle \mathrm{SOR}
$$

Where $S O D_{, i}$ is sediment oxygen demand at the end of the current day, $S O D_{, i-1}$ is sediment oxygen demand at the end of the previous day, $\triangle \mathrm{SOR}$ is additional SOD caused by the current day addition of silt and clay fine sediment to the control volume (note that the consumption rate is based upon the amount present at the midpoint of the period), and; SOC is sediment oxygen consumption for the current day. All units are in mg/L (Alonso et al., 1996).

DO concentration affects SOD according to:

$$
\mathrm{DO}(\mathrm{f})=\left(\mathrm{DO} / \mathrm{DO}_{\mathrm{ref}}\right)^{0.3}
$$

Where $\mathrm{D})(\mathrm{f})$ is the Dissolved oxygen correction factor, DO is the dissolved oxygen of water in a grid cell within the redd domain, and $\mathrm{DO}_{\text {ref }}$ is the saturated dissolved 
oxygen at reference temperature and sea level (mg/L) (after McDonnell and Hall (1967), Theurer \& Theurer (1987), Alonso et al., (1996)).

Oxygen in the water within the interstices in the redd is consumed by both the oxygen consumption of the infiltrated sediment-associated $\mathrm{OM}$ and the incubating salmon eggs. The egg oxygen consumption (EOC) depends upon the number of eggs and their rate of respiration which varies according to the stage of embryo development (Chevalier et al., 1984). EOC is given by the following equation:

$$
E O C=\frac{\mathbf{4} \pi r^{2}\left(D_{o}-D_{o Q}\right)}{\frac{1}{k}+\left(\frac{\delta}{D_{c}}\right)}
$$

Where $r$ is the egg radius $(\mathrm{cm}), D_{0}$ is the concentration of oxygen of the surrounding water $(\mathrm{mg} / \mathrm{cc}), D_{o e}$ is the concentration of oxygen within the egg $\left(\mathrm{mg} / \mathrm{cm}^{3}\right), \mathrm{k}$ is the mass transfer coefficient $(\mathrm{cm} / \mathrm{s}), \delta$ is the egg membrane thickness $(\mathrm{cm})$, and $D_{c}$ is the diffusion coefficient of water through the egg membrane $\left(\mathrm{cm}^{2} / \mathrm{s}\right)$. Parameter values for Atlantic salmon and brown trout are used in SIDO-UK, including the number of eggs, average radius and membrane thickness. The equations controlling hatching time are from Crisp (1981).

The overall rate of oxygen consumption at any model node $(n)$ is given by:

$$
f_{j k}^{n}=(S O D)^{n}{ }_{j k}-(E O C)^{n}{ }_{j k} \delta^{*}\left(j-J_{e}\right)\left(k-K_{e}\right)
$$

in which $\delta^{*}$ is the Dirac delta function, and $\left(\mathrm{J}_{\mathrm{e}}, \mathrm{K}_{\mathrm{e}}\right)$ indicates any cell in the model domain belonging to the egg zone (Alonso et al., 1996). EOC and SOD depend on water temperature (which controls stage of embryo development and hence EOC) and mass of ingressing fines, respectively. EOC and SOD are computed on the same time basis and are assumed to be uniformly distributed over a day period (Alonso et al., 1996).

Full details of the SIDO model process representation can be found in Alonso et al., (1996), Theurer and Theurer (1986) and Pattison et al., (in review). 


\section{Methods}

Since estimates of SOD within spawning gravels are rare, field investigations were undertaken to acquire samples of fine sediments intruded into artificial redds using methods developed by Greig et al. (2005a). Sites were chosen to ensure a representative sample of salmon spawning habitats from England and Wales that are broadly typical of the wider UK (Raven et al., 1994). We included the original four sites used by Greig et al. (2005b), together with additional field sites in rivers draining different lithology (e.g. Rede - sandstone/limestone; Itchen - chalk groundwater dominated rivers), and to provide duplication of river types (e.g. Lugg similar to Ithon/Aran) and (Test similar to Itchen). Summary data on all sites are provided in Table 2 and mapped in Figure 2. In all cases, the sites chosen were known spawning grounds for either Atlantic salmon and/or brown trout.

At each site, two artificial salmon redds were constructed according to the methods outlined in Greig et al., 2005b; 2007b). A single sedimentation basket was inserted into each redd to a depth of $20 \mathrm{~cm}$ which is typical of egg burial depths of Atlantic salmon in UK rivers (Crisp \& Carling 1989). One month after insertion, the baskets were extracted using a pre-installed outer bag to retain the ingressed fine sediments (Grieg et al., 2005) and the sediment samples stored in a cool box (c. $4^{\circ} \mathrm{C}$ ) and transported to the laboratory within 24 hours of sampling.

\section{Laboratory procedure}

The sediment samples collected for SOD measurements were processed following the procedures detailed in Collins et al., (in press - this volume). Samples were wet sieved using river water, and the <63um fraction retained, as previous experience has shown that the highest SOD corresponds to this grain size fraction (Bateman, 2012). Duplicate $200 \mathrm{~mL}$ aliquots of the wet-sieved slurry were subsampled and transferred into $1 \mathrm{~L}$ amber Duran flasks. When all of the bed sediment samples were processed, the flasks were placed in a Gallenkamp temperature controlled orbital incubator set to the average water temperature for the sample river. A shaker speed of circa $100 \mathrm{rpm}$ was used to ensure adequate mixing of the 
sediment samples during the experiment and to mitigate the formation of oxygen gradients within the liquid. The flasks were sealed with tops in which were inserted a calibrated Q-OX MediceL oxygen sensor (Shawcity Technology Ltd, error $<1 \%$ signal) connected to a Delta-T2 data logger. The flask contents were allowed to acclimate to operating conditions (approx. $1 \mathrm{hr}$ ) prior to commencing data logging. Oxygen concentration in the bottle headspace was sampled at 1 minute intervals and logged every 10 minutes for the 25-day duration of the experiment. In order to correct for each individual oxygen probe, a blank experiment was run for 25 days using $200 \mathrm{~mL}$ of ultra-high pure water. At the end of the 25-day measurement period, the dry weight equivalent of sediment in each test vessel was determined by filtering the slurry through dried, pre-weighed GFC filters. The filters were subsequently oven dried for $2 \mathrm{hrs}$ at $100^{\circ} \mathrm{C}$, cooled in desiccators and weighed until constant values were achieved.

The output from the Q-OX MediceL probes was converted into a mass of oxygen in the head space. The SOC rate was calculated from the mass of oxygen consumed in the flask over time:

$$
\mathrm{SOC}=\underline{\left(m_{1}-\underline{m}_{2}\right)}
$$

$$
t
$$

where $\mathrm{SOC}$ is the sediment oxygen consumption rate in $\mathrm{mg} \mathrm{O}_{2}$ day $^{-1}, t$ is time in days, and $m_{1}$ and $m_{2}$ are the mass of oxygen at time 1 and time 2 in the head space. All values were blank corrected. The final values were corrected using a Q10 (or Van't Hoff) equation to normalise the SOC estimates to $20^{\circ} \mathrm{C}$ :

$$
\operatorname{SOC}^{20}=1.065^{(20-T)} \cdot \operatorname{SOC}^{T}
$$

where $\operatorname{SOC}^{20}$ is the rate at $20^{\circ} \mathrm{C}$, and $T$ is the water temperature during measurement in degrees Celsius (Thomann and Mueller, 1987; Doyle and Lynch 2005). This correction applies to temperatures of $10^{\circ} \mathrm{C}$ or more which was the 
incubation temperature used in the experiments. The resulting rates were used to calculate the total mass of oxygen consumed over $0-5$ days $\left(\mathrm{SOC}_{5}\right)$ and $0-20$ days $\left(\mathrm{SOC}_{20}\right)$, respectively. These values were divided by the dry mass of sediment used in each flask to give SOD values in $\mathrm{mg} \mathrm{O}_{2} \mathrm{~g}^{-1}$ dry sediment. Five days is a standard time period used to observe the oxygen demand of organic effluents and sewage wastes on water. A 25-day time period is considered by convention to be an adequate time for the complete biochemical oxidation of organic material within water samples, sometimes known as the total BOD (Delzer and Mckenzie 2003). It was considered that the 5 and 20 day periods used in the measurement of SOD are significant to incubating fish embryos since these rates provide a more accurate account of oxygen consumption by channel bed sediment over the embryo incubation period. It is critical to understand the longer-term SOC of river channel bed sediments given the propensity for sediment retention in UK lowland rivers (e.g. Naden et al., 2016) and the need to take into account the oxygen demand imparted by deposited sediment-associated OM (Sear et al., 2008).

\section{SIDO-UK modelling}

A previously calibrated SIDO-UK model for the Ithon (Pattison et al., in review) was used to assess the SOD effect upon Atlantic salmon eggs. The effect of SOD is reliant upon the mass of accumulated fines, which is the variable used to calibrate the model. The mean error on the final accumulated mass was $2.5 \%$, and the simulated percentage was within the range of the two field observations given by the retrievable baskets.

Firstly, a sensitivity analysis of SIDO-UK to the two parameters which control the rate of oxygen consumption by the fine sediment, SOC and $k$, was carried out. SOC is the oxygen consumption rate at day 20 at $20^{\circ} \mathrm{C}$, while $\mathrm{k}$ is the deoxygenation decay constant. $k$ is calculated via the following equation:

$$
k=\frac{\Sigma t_{i} l n\left(1-\frac{5 O C_{i}}{S O D}\right)}{\Sigma\left(t_{i}^{2}\right)}
$$


Where $\mathrm{SOC}_{i}$ is the sediment oxygen consumption rate at time $\mathrm{t}$ at node $\mathrm{i}$ in the model, and $S O D$ is the sediment oxygen demand at $20^{\circ} \mathrm{C}$.

$k$ values were calculated from the measured SOC rate and overall SOD data for the 12 catchments, using SOC rates at time 0-5 and 5-15 days, and SOD over 20 days. $\mathrm{SOC}$ is calculated by equation 8 . Figure 3 shows the relationship between SOD, $\mathrm{k}$ and SOC. The SOC rates decline over time, with the rate (gradient) dependent upon the $\mathrm{k}$ (deoxygenation decay constant) parameter. The overall magnitude of SOC rate is controlled by the overall SOD parameter. The literature (Bateman 2012; Grieg et al., 2005; Greig 2004; Alonso et al., 1996) was used to define the range of the parameters, with $S O D$ ranging from 1 to $90 \mathrm{mgO}_{2} \mathrm{~g}^{-1}(1,5,10,15,20,30,40,50,60$, $\left.70,80,90 \mathrm{mgO}_{2} \mathrm{~g}^{-1}\right)$, and $k$ from 0.0001 to $0.2(0.0001,0.0005,0.001,0.005,0.01$, $0.05,0.1,0.15,0.2)$. Overall, 108 simulations were run within this parameter space using the Ithon as a case study. The SIDO-UK model has not been specifically validated in terms of the effect of fine sediment on DO for the Ithon, but a previous study (Sear et al., 2014) found that for the Rede, the SIDO-UK model predicted DO concentrations within the range of field measurements. Experimental data from all the study rivers were then used to calculate corresponding values for SOD and $k$ (equation 13) and then plotted within the parameter space for the Ithon to identify which rivers were more/less sensitive to the effect of SOD. The average set of values for each catchment were calculated to show the range of values in the UK. The influence of mass of fines upon the sensitivity to SOD and k was assessed by looking at different times (Days 62, 76 and 100) through the simulation. Key outputs such as SOC rate, DO and \% eggs whose oxygen demands are met by the oxygen available, were assessed.

Scenarios representing the average values of SOD and $k$ decay constants (Table 3 ) from various UK catchments were then compared using the calibrated Ithon SIDOUK model, as calibrated models were unavailable for all catchments. This allowed the effect of $S O D$ alone to identified, as the time series of sediment inputs, blocking effect of sediment on intra-gravel flow velocity, supply of DO and egg survival, were kept constant between simulations. Thus, any variations predicted were due to changes in SOD.

\section{Statistical analysis}


In order to understand catchment influences on SOD and SOC, relationships between catchment, site and sediment characteristics, and SOD and SOC were explored using ordination. Principal component analysis was used to describe variation in catchment land use (\% cover from Land Cover Map) and environmental characteristics among the field sites. To understand better the relationship between measured SOD and SOC and wider catchment characteristics, redundancy analysis was first used to establish relationships between catchment land use and sediment characteristics, and the significance of explanatory variables tested with forward selection using Monte Carlo permutation tests $(\mathrm{n}=999$ permutations, $P<0.05$ with Bonferroni correction for number of variables included). As only the first two axes were significant, to enable visualization of relationships between catchment land use, sediment composition and SOD, contours of variation in $\mathrm{SOD}_{5}$ and $\mathrm{SOD}_{20}$ were then superimposed on the relationship passively (i.e. without influencing the underlying ordination) based on measured $\mathrm{SOD}_{5}$ and $\mathrm{SOD}_{20}$ of the sediment samples and smoothed using loess.

\section{Results}

The principal aim of the work was to quantify the effect of SOD on the oxygen supply to salmon embryos.

The land use in the catchment and the physical characteristics of the interstitial sediments varied markedly among the study catchments (Figure 4). It should be noted that land use was \% cover of the catchments leading to a separation of intensive and extensive land uses. Similarly, the SOD of silt/clay material in salmon redds sampled within the same spawning season (Dec 2010 - March 2011), was highly variable between different rivers (Figure 5).

The sensitivity of redd abiotic conditions and egg survival to SOD are shown in Figure 6. The effect of SOD is complex, and is dependent on the ultimate SOD rate, the rate of decay over time and the mass of sediment added. The mass added is further complicated by residual SOD effects from sediment added in previous time steps. Figure 6a shows the SOC rate at different time steps, as mass added at that time step decreases from left to right, but total infilled sediment increases. As the mass added increases, the SOC rate increases. The black dots show the average SOD over the simulated time period and $k$ values for the UK catchments, with the 
Itchen having the highest SOD value, and the Lod having the highest $\mathrm{k}$ value. The Rede was the most sensitive to SOD, as it had a higher than average SOD value and the second lowest $k$ value. This means that ultimate SOD started high and decayed slowly. The effect of this on DO was more complex, as this was dependent upon previous time steps. Therefore, the most influential factor here was the whole time series, rather than the discrete time steps. As the total mass of sediment in the redd increased, the DO decreased. However, this effect can be attributed singly to the SOD as everything else was kept constant. The UK catchments at day 62 (just after the first sediment input) were insensitive ( $<5 \%$ from baseline) to SOD in terms of the DO concentration. At day 76, four catchments (Rede, Itchen, Frome, Axe) had a value $>10 \%$ from the baseline value, with the Rede having the highest value of $\sim 15 \%$ from baseline. By 100 days, all but the Lugg catchment had a value of $>10 \%$, and the Rede had a value of $\sim 25 \%$. Finally, in terms of the sensitivity of egg survival to SOD, Figure $6 \mathrm{c}$ shows that there was up to a $4.5 \%$ difference in the percentage of eggs being satisfied with their oxygen demand over the range of SOD values found in the river sediments sampled.

Figure 7 shows the differences in egg incubation conditions between different UK rivers, which had different observed SOD rates. Figure $7 a$ shows the SOC rate for the various rivers over the incubation period. SOC rate is a function of both the initial ultimate SOD and the decay rate; k. Of the 12 UK catchments included in this study, influence of SOC was highest in the Rede, where the maximum rate was $1.5 \mathrm{mg} \mathrm{L}^{-1}$ at day 66. The Itchen also experienced a high effect of SOC, while the influence of SOC was very small in the Lugg. Figure $7 \mathrm{~b}$ and $7 \mathrm{c}$ show how SOC controls the DO concentration. Small amounts of fine sediment seemed to make no difference to the DO, and did not have a significant impact until the SOC rate was greater than $\sim 0.2$ $\mathrm{mg} \mathrm{L}^{-1}$. In addition to the consumption of oxygen by the sediment and eggs, DO concentration is influenced by the blocking effect of sediment and hence, a reduction in the supply of oxygen rich water through sufficient intra-gravel flow velocities. This effect was constant in all simulations, but the effect of SOC alone was isolated in Figure $7 \mathrm{c}$ by subtracting a baseline scenario with no SOD influence (SOD $=0, k=0$ ). The greatest effect of SOC was seen at day 79, where for the Rede, the DO concentration was reduced by $2.03 \mathrm{mg} \mathrm{L}^{-1}$ due to the SOC effect alone. Figure $7 \mathrm{~d}$ and 7 e show how this impacted upon the percentage of eggs satisfied in terms of 
their oxygen demand. Overall, SOC alone made little difference to the percentage of eggs surviving to hatch, with the largest effect seen for the Rede, where the number of eggs hatching was reduced by $1.53 \%$. However, SOC had more of an effect on the timing of egg mortality or possible sub-lethal effects. Eggs in the Rede hatched two days later due to the SOC effect alone, while in all other rivers, except the Lod and the Lugg, it was a day later. Furthermore, the timing of when eggs were not being satisfied in terms of oxygen could be different by up to three days, and the magnitude of the change caused by SOC alone could be $\sim 21 \%$.

Redundancy analysis indicated that catchments with a high cover of arable land (as arable horticulture, arable cereals or non-rotational horticulture) tended to have more organic river sediments, both in terms of \% organic and mass of OM (Figure 8). Arable horticulture was also associated with high \% silt in the sediment, as was calcareous grassland. It should be noted that the \% cover data resulted in a tendency to exclude extensive land uses from the model, as they were negatively associated with the intensive land use types included (see Figure 3) and added no further explanatory power. $\mathrm{SOD}_{5}$ tended to be higher in sediments with higher organic content, and those sediments with higher \% clay (and to a lesser extent \% silt): these comprised sites with more arable land in their catchments (Figure 8a). However, $\mathrm{SOD}_{20}$ demonstrated a slightly different pattern, being highest in sediments with a high \% silt and mass of OM, from catchments with more calcareous grassland and arable horticulture: in contrast to $\mathrm{SOD}_{5}$, sediments with a high \% clay had relatively low $\mathrm{SOD}_{20}$ (Figure $8 \mathrm{~b}$ ).

\section{Discussion}

The SOD values reported from the different rivers show strong site and catchment variability. Reasons for this are likely to be a function of the type of OM (Lundkvist et al., 2007); the quantity of OM (Thomann and Mueller, 1987) and particle size (House, 2003). These might be expected to vary with the catchment type. Whilst the data shows some differences between broad catchment types (semi-natural woodland<upland<mainstem<chalk), within these, there are considerable sitespecific differences in SOD. These are possibly the result of differences in OM content (Tank et al., 2010), proportion of silt to clay or the type of OM and biological 
communities involved in the breakdown of OM within the redds (Yoshimura et al., 2008). Our analysis indicates that higher $\mathrm{SOD}_{5}$ appears to be associated with a higher organic content in the sediment and more intensive land use, particularly a higher proportion of arable land (of all types), in the catchment, whereas $\mathrm{SOD}_{20}$ is more associated with arable horticulture and a high proportion of silt in the sediment. For groundwater dominated catchments (Frome, Itchen and Test), higher $\mathrm{SOD}_{5}$ may be a function of large instream biomass, emphasizing he need for organic matter source apportionment in future studies of SOD.

Our results support the assumption that SOD increases with increasing OM content (Thomann and Mueller, 1987), although some studies have found no relation between OM content and SOD (Seiki et al., 1994, Caldwell and Doyle, 1995). In our analysis, there is no relationship between mass or proportion of $\mathrm{OM}$ and $\mathrm{SOD}_{20}$ (Figure 8). A similar result was found for $\mathrm{SOD}_{5}$. Similarly, the mass and proportion of clay within the samples showed no relationship with 20-day or 5-day SOD (Figure 8). It was beyond the scope of this study to explore the specific OM composition, but the results indicate that the variations in SOD between catchments and between samples from the same catchment are most likely the result of differences in the OM composition (Tank et al., 2010; Yoshimura et al., 2008). The source and size of OM is known to influence the rate of microbial decomposition and the respiration of these biological communities (Tank et al., 2010; Yoshimura et al., 2008). FPOM (<100um) which comprised much of the organic material in our sediment samples, is mostly made up of amorphous OM (Wotton, 2007). It originates from direct inputs from the terrestrial environment (Ward, 1986), fragmentation and maceration of CPOM (Ward, 1984), and aggregation of colloidal (Wotton, 1990) or dissolved organic matter (DOM; Petersen, 1986). Whilst Yoshimura et al. (2008) found that the oxygen demand of FPOM was less than CPOM due to the increased concentration of refractive carbon (lignin), Bateman (2012) found higher rates of SOD in <63um particles. Yoshimura et al.'s (2008) experiments were based on organic sources derived from wood and leaf fragments. In agricultural catchments, additional sources are likely to come from soil erosion, animal and human waste, as well as autochthonous sources such as invertebrate faecal pellets, fish carcasses and aquatic plant fragments (Richardson et al., 2005; Collins et al. 2014). Research is required to determine the active components of oxygen demand within fine 
sediments of different river systems and to establish the sources of these materials. A limitation of the SIDO-UK and SIDO modelling platform in relation to sources of SOD include the lack of representation of oxygen consumption from biofilms covering larger framework clasts (although it will be included in empirical values of SOD for interstitial fines), other organisms (e.g. invertebrates and diatoms), and the SOD arising from larger particles that comprise a higher proportion of the infiltrated fines than that currently represented. Additional research is required to identify the magnitude of these different sources in relation to the spawning timing of salmonids.

SIDO-UK and SIDO are 2-dimensional process-based models that seek to couple explicitly, the surface hydrodynamics and sediment transport processes to subsurface hyporheic flows, sedimentation and DO processes using a mass balance approach to establish the interaction between incubating salmonid embryos and the supply rate of DO, thus predicting when embryo mortality occurs. SIDO and SIDOUK are still the only models that incorporate all the key processes within a salmonid spawning redd environment, though Sear et al., (2014) highlight the limitations in applying the models to spawning substrates strongly influenced by upwelling groundwater. Whilst more complex 2D and 3D hyporheic flow models have been developed (e,g. Cardenas et al., 2016; Tonina \& Buffington 2009) that represent turbulent exchange processes at the streambed, hyporheic flows through complex 3D topography and include upwelling groundwater, to date they are not capable of fully representing fine sedimentation processes, SOD and biological processes of salmonid incubation. Similarly, Wu (2000), for example, present more complex models of fine sediment accumulation, but in this case, fines are typically defined by sand sizes rather than silts and clays that are critical for salmonid survival, and they do not explicitly model SOD or embryo survival. Notwithstanding these limitations, there is clearly scope for improving process representation within the hyporheic zone, including better representation of sources and sinks of DO, and improved representation of flow and DO fluxes building on more recent hyporheic modelling frameworks.

\section{Acknowledgements}


The authors gratefully acknowledge the funding provided by the Department for Environment, Food and Rural Affairs (Defra) under project WQ0128 (Extending the evidence base on the ecological impacts of fine sediment and developing a framework for targeting mitigation of agricultural sediment losses). LOI and sediment analysis were undertaken by Peter Morgan and Jenny Stanford. Sediment samples were collected by ADAS UK Ltd. staff.

\section{References}

Alonso CV, Theurer FD, Zachman DW. 1996. Sediment Intrusion and dissolved oxygen transport model - SIDO. Technical Report No. 5, USDA-ARS National Sedimentation laboratory, Oxford, Mississippi; 232p.

https://iapreview.ars.usda.gov/Business/docs.htm?docid=5229

Ballantine DJ, Walling DE, Collins AL, Leeks GJL 2009. The content and storage of phosphorus in fine-grained channel bed sediment in contrasting lowland agricultural catchments in the UK. Geoderma 151: 141-149.

Bateman SJ. 2012. Sources and impacts of inorganic and organic fine sediment in salmonid spawning gravels in chalk rivers, Unpublished PhD Thesis, Geography \& Environment, University of Southampton , 368pp.

Caldwell J M, Doyle MC. 1995. Sediment oxygen demand in the lower Willamette River, Oregon, 1994. U.S. Geological Survey, U.S. Department of Interior, WRIR 954196, Portland, OR, USA. 20p.

Chapman DW. 1988. Critical review of variables used to define effects of fines in redds of large salmonids. Transactions of the American Fisheries Society 117: 1-21.

Cardenas MB, Ford AE, Kaufman M, Kessler AL, Cook AJL. 2016. Hyporheic flow and dissolved oxygen distribution in fish nests: The effects of open channel velocity, permeability patterns, and groundwater upwelling, Journal of Geophysical Research: Biogeosciences.121, 3113-3130, doi:10.1002/ 2016JG003381. 
Chau KW. 2002. Field Measurements of SOD and Sediment Nutrient Fluxes in a Land-Locked Embayment in Hong Kong. Advances In Environmental Research 6: 135-142.

Chevalier B, Murphy VG. 1985. Intragravel dissolved oxygen model. Colorado State University, Dept. Agr. And Chem. Eng., ARS Project No. 5402-20810-004-01S, pp.66.

Chevalier BC, Carson C, Miller WJ. 1984. Report of engineering and biological literature pertaining to the aquatic environment: with special emphasis on dissolved oxygen and sediment effects on salmonid habitat. Colorado State University, Dept. Agr. And Chem. Eng., ARS Project No. 5602-20813-008A.

Collins AL, Zhang YS, McMillan S, Dixon ER, Stringfellow A, Bateman, S., Sear DA, in press. Sediment-associated organic matter sources and sediment oxygen demand in a Special Area of Conservation (SAC); a case study of the River Axe, UK. River Research and Applications.

Collins AL, Williams LJ, Zhang YS, Marius M, Dungait JAJ, Smallman DJ, Dixon ER, Stringfellow A, Sear DA, Jones JI \& Naden PS (2014) Sources of sediment-bound organic matter infiltrating spawning gravels during the incubation and emergence life stages of salmonids. Agriculture, Ecosystems and Environment 196: 76-93.

Cole, TM, Wells, SA. 2008. CE-QUAL-W2: a Two-dimensional, Laterally Averaged, Hydrodynamic and Water Quality Model, Version 3.6. U.S. Army Corps of Engineers Instruction Report EL-08-1. 366 pp.

Cox, B.A. 2003. A review of dissolved oxygen modelling techniques for lowland rivers, Science of the Total Environment, 314-316, 303-334.

Daykin P. 1965. Application of mass transport theory to the problem of respiration of fish eggs. Journal of the fisheries Research Board of Canada 22: 159-170. 
DeVries PD. 2008. Bed disturbance processes and physical mechanisms of scour in salmonid spawning habitat, in Sear DA, DeVries P. (ed) Salmonid Spawning habitat in Rivers; Physical controls, biological responses and approaches to remediation. AFS, Bethesda, Maryland, USA; 121-148.

Di Torro M, 2001. Sediment flux modelling, New York, Wiley, pp. 624.

Doyle MC, Lynch DD, 2005. Sediment oxygen demand in Lake Ewauna and the Klamath River, Oregon, June 2003. U.S. Geological Survey Scientific Investigations Report 05-5228, 14 p.

Doyle, M.C., Rounds, S.A., 2003, The effect of chamber mixing velocity on bias in measurement of sediment oxygen demand rates in the Tualatin River Basin, Oregon: U.S. Geological Survey Water-Resources Investigations Report 03-4097, 16 p.

ECASOP-SODSOP6.0 2007. Sediment Oxygen Demand Determination, Standard Operating Procedure, Rev 6.0, July 18, 2007.

Edwards RW, Rolley HLJ, 1965. Oxygen consumption of river muds, Journal of Ecology, 53: 1-19.

Greig SM 2004. An assessment of factors influencing the ability of UK spawning gravels to support the respiratory requirements of Atlantic Salmon (Salmo salar) embryos. Unpublished PhD Dissertation, School of Geography, University of Southampton; 322pp

Greig SM, Sear DA, Carling PA. 2005. The impact of fine sediment accumulation on the survival of incubating salmon progeny: Implications for sediment management. The Science of the Total Environment, 344: 241-258.

Greig SM, Sear DA, Carling PA. 2007a. Review of factors influencing the availability of dissolved oxygen to incubating salmon embryos. Hydrological Processes, 21, 3: 323-324. 
Greig SM, Sear DA, Carling P.A. 2007b. A field-based assessment of oxygen supply to incubating Atlantic salmon embryos. Hydrological Processes 22: $3087-3100$.

Hamor T and Garside ET, 1976. Developmental rates of embryos of Atlantic salmon, Salmo salar, in response to various levels of temperature, dissolved oxygen and water exchange. Canadian Journal of Zoology 54: 1912-1917.

Heckathorn HA, Gibs J. 2010. Sediment oxygen demand in the Saddle River and Salem River watersheds, New Jersey, July-August 2008. U.S. Geological Survey Scientific Investigations Report 2010-5093, 10 p.

Hendricks SP. 1993. Microbial Ecology Of The Hyporheic Zone - A Perspective Integrating Hydrology And Biology. Journal of the North American Benthological Society ,12:1, 70-78.

House WA. 2003. Factors influencing the extent and development of the anoxic zone in sediments. Biogeochemistry, 63: 317-333.

Jewell WJ, McCarty PL. 1971. Aerobic decomposition of algae. Envir, Sci Technol., 5: 1023-1031.

Josium RM, Stefan HG. 1999. Effect of low velocity on sediment oxygen demand: comparison of theory and experiments, Journal of the American Water Resources Association 35, 2: 433-439.

Lawler, D.M., Cardenas, B. Old, G.H. and Sear, D.A. 2009. Geomorphology and Sediments of the Hyporheic Zone, In: The Hyporheic Handbook. A handbook on the groundwater-surface water interface and hyporheic zone for environmental managers. Integrated catchment science programme. Environment Agency Science report: SC050070, Chapter 3, pp. 16-47 \& 231-236.

Liu, W.C., Chen, W.B. 2011 Monitoring sediment oxygen demand for assessment of dissolved oxygen distribution in river, Environ. Monit. Assess. 184, 9: 5589-5599. 
Lundkvist M, Grue M, Friend PL, Flindt MR. 2007. The relative contributions of physical and microbiological factors to cohesive sediment stability. Continental Shelf Research 27: 1143-1152.

Malcolm IA, Greig SM, Youngson AF, Soulsby C. 2008. Hyporheic influences on salmon embryo survival and performance in Sear DA,DeVries P. (Eds.) Salmonid Spawning habitat in Rivers; Physical controls, biological responses and approaches to remediation, AFS, Bethesda, Maryland, USA; 225-248.

McDonnell AJ, Hall SD. 1969. Effects of mixing on environmental factors on benthal oxygen uptake. J. Water Pollut. Control Fed. 41: 353_363.

Miskewitz RJ, Francisco KL,Uchrin CG. 2010. Comparison of a novel profile method to standard chamber methods for measurement of sediment oxygen demand. Journal of Environmental Science and Health Part A, 45, 7: 795-802.

Nakamura Y, Stefan HG. 1994. Effect of Flow Velocity on Sediment Oxygen Demand: Theory. Journal of Environmental Engineering, ASCE 120, 5:996-1016.

Olsson TI, Persson B. 1988. Effects of deposited sand on ova survival and alevin emergence in brown trout (Salmo trutta L.). Archiv fur Hydrobiol. 113: 621-627.

Otten, J., Gons, H.J., Rijkeboer, M., 1992. Dynamics of phytoplankton detritus in a shallow, eutrophic lake (Lake Loosdrecht, The Netherlands). Hydrobiologia 233, 6167.

Palmer MA, Bernhardt ES, Allan FD, et al. 2005. Standards for ecologically successful river restoration, Journal of Applied Ecology, 42: 2, 208-217.

Petersen RC. 1986. In situ particle generation in a southern Swedish stream. Limnology and Oceanography 31:432-437. 
Parrish DL, Behnke RJ, Gephard SR, McCormick SD, Reeves GH. 1998.Why aren't there more Atlantic salmon (Salmo salar)?, Canadian Journal of Fisheries and Aquatic Science 55, 1: 281-287.

Patterson, D.J., Epstein, E., McEvoy, L. 1975, Water pollution investigation Lower Green Bay and Lower Fox River, USEPA Report EPA-905/9-74-017 (1975), p. 371

Quinn TA. 2005. The behavior and ecology of Pacific salmon and trout. American Fisheries Society, Bethesda, Maryland, 320p.

Richardson JS, Bilby RE, Bondar CE. 2005. Organic Matter Dynamics in Small Streams of the Pacific Northwest. Journal of the American Water Resources Association (JAWRA) 41, 4: 921-934.

Sear DA. 2010. Integrating science and practice for the sustainable management of in-channel salmonid habitat, in Kemp, P. (Ed.) Salmonid Fisheries: Freshwater habitat management, Wiley Blackwell, Chichester, UK, 81-111.

Sear DA, DeVries P, Greig SM. 2008. Science and the practice of salmonid spawning habitat remediation, in Sear, D.A. \& DeVries, P. (ed) Salmonid Spawning habitat in Rivers; Physical controls, biological responses and approaches to remediation, AFS, Bethesda, Maryland, USA, , 1-13.

Sear DA, Frostick LB, Rollinson G,Lisle, T.E. 2008. The significance and mechanics of fine sediment infiltration and accumulation in gravel spawning beds, in Sear, D.A. \& DeVries, P. (ed) Salmonid Spawning habitat in Rivers; Physical controls, biological responses and approaches to remediation, AFS, Bethesda, Maryland, USA,149-174.

Seiki T, Izawa H, Date E, Sunahara H.. 1994. Sediment Oxygen-Demand In Hiroshima Bay. Water Research 28:385-393. 
Soulsby C, Malcolm IA, Youngson AF, Tetzlaff D, Gibbins CN, Hannah DM. 2005. Groundwater - surface water interactions in upland Scottish rivers: hydrological, hydrochemical and ecological implications. Scottish Journal of Geology 41: 39-49.

Stuart TA. 1953. Water currents through permeable gravels and their significance to spawning salmonids. Nature 172: 407-408.

Tank JL, Rosi-Marshall EJ, Griffiths NA, Entrekin SA, Stephen ML. 2010. A review of allochthonous organic matter dynamics and metabolism in streams, J. N. Am. Benthol. Soc., 29, 1:118-146.

Theurer FD, Theurer KM. 1986. Draft Tucannon River offsite study: dissolved oxygen consumption, USDA unpublished draft report; 28 pp.

Thomann RV, Mueller JA. 1987. Principles of surface water quality modeling and control. Harper International Edition, Harper and Row, New York, NY. 488.

Tonina D, Buffington JM. 2009. A three-dimensional model for analyzing the effects of salmon redds on hyporheic exchange and egg pocket habitat, Can. J. Fish. Aquat. Sci., 66 (12), 2157-2173, doi:10.1139/f09-146.

Utley, B. C., Vellidi, G., Lowrance, R., \& Smith, M. C. 2008. Factors affecting sediment oxygen demand dynamics in blackwater streams of Georgia's coastal plain. Journal of the American Water Resources Association, 44(3), 742-753.

Ward GM. 1984. Size distribution and lignin content of fine particulate organic matter (FPOM) from microbially processed leaves in an artificial stream. Verhandlungen der Internationalen Vereinigung fu" $r$ theoretische und angewandte Limnologie 22:18931898.

Ward G M. 1986. Lignin and cellulose content of benthic fine particulate organic matter (FPOM) in Oregon Cascade Mountain streams. Journal of the North American Benthological Society 5:127-139. 
Wotton R S. (EDITOR). 1990. The biology of particles in aquatic systems. Lewis Publishers, Boca Raton, Florida.

Wotton RS. 2007. Do benthic biologists pay enough attention to aggregates formed in the water column of streams and rivers? Journal of the North American Benthological Society 26:1-11.

WWF. 2001. The Status of Wild Atlantic Salmon: a River by River Assessment. World Wildlife Fund European Freshwater Programme, Copenhagen. 98p.

Wu F-C. 2000. Modeling embryo survival affected by sediment deposition into salmonid spawning gravels: Application to flushing flow prescriptions, Water Resources. Research, 36, 1595-1603, doi:10.1029/2000WR900021.

Yoshimura CM, Gessener O, Tockner K, Furumai H. 2008. Chemical properties, microbial respiration, and decomposition of coarse and fine particulate organic matter. Journal of the North American Benthological Society 27:664-673.

Ziadat AH, Berdanier BW. 2004. Stream depth significance during in-situ sediment oxygen demand measurements in shallow streams, Journal of the American Water Resources Association 40, 3: 631-638. 


\section{Tables and Figures}

Table 1: Sediment Oxygen Consumption (SOC) values reported from field sites measured using in-situ or laboratory methods. Note only 2 sites report values from spawning gravels.

Table 2: Mean and standard deviation (italics) of the physical characteristics and SOD from a range of salmonid rivers. Underlined names are groundwater-dominated chalk streams. All others are runoff-dominated gravel-bed rivers.

Table 3: Average Sediment Oxygen Demand (SOD) and k values for different UK gravel-bed rivers (with standard deviations where sample size permitted).

Figure 1: Theoretical graph showing how Sediment Oxygen Demand (SOD) of sediment changes over time in a standard 30 day test at $20^{\circ} \mathrm{C}$.

Figure 2: Location of study sites and catchments. Sites cover a range of salmon rives types, from lowland, chalk groundwater dominated gravel rivers to headwater gravel-cobble bed streams in upland catchments draining impermeable igneous geology.

Figure 3: Variation in a) land use, as percentage cover, among the study catchments (centroids shown as $\boldsymbol{\Delta}$ ), and b) characteristics of field sites used (sites shown as $\circ$ ).

Figure 4: Sensitivity of Sediment Oxygen Consumption (SOC) to SOD and k coefficients.

Figure 5: Variation in $\mathrm{SOD}_{20}$ and $\mathrm{SOD}_{5}$ across the study catchments. Itchen, Frome and Test are all groundwater dominated rivers with high instream biomass.

Blackwater is a semi-natural woodland stream. The Lod represents only one sample.

Figure 6: Sensitivity analysis of a) SOC; b) DO; and c) \% egg survival to different SOD and de-oxygenation rates, at different times within the SIDO-UK model River Ithon simulation.

Figure 7: Time series of a) SOC b) absolute DO; c) DO reduction caused by SOC alone; d) egg survival; and e) change in egg survival caused by SOC alone; for a range of different river types sampled in this study. 
Figure 8: Results of Redundancy Analysis (RDA) showing that catchment land use cover is significantly associated with variation in sediment characteristics, with contours of a) $\mathrm{SOD}_{5}$ and b) $\mathrm{SOD}_{20}$ of sediment samples. Sample sites shown as (o). 


\begin{tabular}{|l|l|l|l|l|}
\hline \multicolumn{1}{|c|}{ Location } & \multicolumn{1}{c|}{ SOC } & Substrate & \multicolumn{1}{c|}{ Method } & \multicolumn{1}{c|}{ Reference } \\
\hline Klamath River & $1.58-1.84 \mathrm{mg} \mathrm{m}^{-2}$ day $^{-1}$ & Silts/Sands & In-Situ & Doyle and Rounds, (2003) \\
\hline River Hiz & $1.75-3.25 \mathrm{mg} \mathrm{m}^{-2}$ day $^{-1}$ & Silts/clays & Laboratory & Edwards and Rolley, (1965) \\
\hline Xindian River & $4.39-5.35 \mathrm{mg} \mathrm{m}^{-2}$ day $^{-1}$ & Silts/clays & In-Situ & Liu et al, (2011) \\
\hline Suwannee River & $0.1-2.3 \mathrm{mg} \mathrm{m}^{-2}$ day $^{-1}$ & Sands & In-Situ & Utley et al., (2008) \\
\hline River Tucannon & $0.13-0.59 \mathrm{mg} \mathrm{g}^{-1}$ day $^{-1}$ & Gravel & Laboratory & Alonso et al., (1996) \\
\hline River Test & $0.94 \mathrm{mg} \mathrm{g}^{-1}$ day $^{-1}$ & Gravel & Laboratory & Greig et al., (2005) \\
River Blackwater & $0.41 \mathrm{mg} \mathrm{g}^{-1}$ day $^{-1}$ & Gravel & & \\
River Ithon & $0.58 \mathrm{mg} \mathrm{g}^{-1}$ day $^{-1}$ & Gravel & & \\
River Aran & $1.19 \mathrm{mg} \mathrm{g}^{-1}$ day $^{-1}$ & Gravel & & \\
\hline
\end{tabular}

Table 1 


\begin{tabular}{|c|c|c|c|c|c|c|c|c|c|}
\hline River & $\%$ Silt & \%Clay & $\begin{array}{c}\text { Mass } \\
\text { Organic } \\
\text { (g) }\end{array}$ & $\begin{array}{c}\% \\
\text { Organic }\end{array}$ & $\begin{array}{c}\mathrm{SOD}_{5} \\
\left(\mathrm{mgO}_{2} / \mathrm{g}\right)\end{array}$ & $\begin{array}{c}\mathrm{SOC}_{5} \\
\left(\mathrm{mgO}_{2} / \mathrm{g} / \text { day }\right)\end{array}$ & $\begin{array}{c}\mathrm{SOD}_{20} \\
\left(\mathrm{mgO}_{2} / \mathrm{g}\right)\end{array}$ & $\begin{array}{c}\mathrm{SOC}_{20} \\
\left(\mathrm{mgO}_{2} / \mathrm{g} / \text { day }\right)\end{array}$ & $\begin{array}{c}\mathrm{SOD}_{20} 20 \mathrm{t} \\
\mathrm{mgO}_{2} / \mathrm{g}\end{array}$ \\
\hline \multirow[t]{2}{*}{ Blackwater } & 77.98 & 19.06 & 0.029 & 15.30 & 1.33 & 0.27 & 4.41 & 0.22 & 8.26 \\
\hline & 8.14 & 4.13 & 0.025 & 11.89 & 1.49 & 0.30 & 4.14 & 0.21 & 7.76 \\
\hline \multirow[t]{2}{*}{ Axe } & 80.92 & 19.08 & 0.035 & 30.75 & 20.02 & 4.00 & 8.76 & 0.44 & 16.43 \\
\hline & 6.95 & 6.95 & 0.030 & 30.24 & 6.94 & 1.39 & 8.26 & 0.41 & 15.49 \\
\hline \multirow[t]{2}{*}{ Esk } & 81.94 & 18.06 & 0.007 & 4.95 & 6.21 & 1.24 & 27.44 & 1.37 & 51.45 \\
\hline & 2.98 & 2.98 & 0.004 & 3.73 & 4.83 & 0.97 & 23.80 & 1.19 & 44.63 \\
\hline \multirow[t]{2}{*}{ Lod } & ND & ND & ND & ND & 1.18 & 0.24 & 1.53 & 0.08 & 2.86 \\
\hline & ND & ND & ND & ND & 1.48 & 0.30 & ND & ND & ND \\
\hline \multirow[t]{2}{*}{ Lugg } & 88.72 & 11.27 & ND & 7.26 & 1.16 & 0.23 & 4.10 & 0.20 & 7.69 \\
\hline & 1.71 & 1.71 & ND & 0.00 & 0.95 & 0.19 & 3.59 & 0.18 & 6.73 \\
\hline \multirow[t]{2}{*}{ Ithon* } & 92.31 & 7.69 & 0.251 & 11.00 & 2.43 & 0.49 & 6.23 & 0.31 & 11.68 \\
\hline & 1.44 & 1.44 & 0.033 & 0.00 & 1.44 & 0.29 & 1.99 & 0.10 & 3.74 \\
\hline \multirow[t]{2}{*}{ Aran* $^{*}$} & 91.82 & 8.18 & 0.294 & 9.00 & 4.10 & 0.82 & 12.65 & 0.63 & 23.73 \\
\hline & 2.12 & 2.12 & 0.206 & 0.76 & 2.20 & 0.44 & 10.90 & 0.55 & 20.44 \\
\hline \multirow[t]{2}{*}{ Rede } & 84.50 & 15.50 & 0.003 & 1.80 & 35.13 & 7.03 & 20.80 & 1.04 & 39.00 \\
\hline & 3.81 & 3.81 & 0.002 & 1.39 & 27.24 & 5.45 & 8.47 & 0.42 & 15.88 \\
\hline \multirow[t]{2}{*}{ Towy } & 84.51 & 15.49 & 0.004 & 3.42 & 5.31 & 1.06 & 13.14 & 0.66 & 24.63 \\
\hline & 3.62 & 3.62 & 0.002 & 2.43 & 2.66 & 0.53 & 5.21 & 0.26 & 9.77 \\
\hline \multirow[t]{2}{*}{ Itchen } & ND & ND & 0.082 & 12.58 & 24.00 & 7.52 & 29.83 & 1.74 & 55.93 \\
\hline & ND & ND & 0.008 & 2.22 & 8.46 & 8.30 & 10.05 & 0.89 & 18.84 \\
\hline \multirow[t]{2}{*}{ Frome } & 84.40 & 15.60 & 0.093 & 35.40 & 4.57 & 0.91 & 24.81 & 1.24 & 46.51 \\
\hline & 4.85 & 4.85 & 0.056 & 19.46 & 2.58 & 0.52 & 14.31 & 0.72 & 26.84 \\
\hline \multirow[t]{2}{*}{$\underline{\text { Test }}^{*}$} & 96.69 & 3.31 & 0.419 & 20.00 & 3.23 & 0.65 & 10.06 & 0.50 & 18.86 \\
\hline & 0.28 & 0.28 & 0.000 & 0.00 & 0.76 & 0.15 & 1.90 & 0.10 & 3.57 \\
\hline
\end{tabular}

* data from Greig (2004)

Table 2: 


\begin{tabular}{|l|c|c|c|}
\hline \multicolumn{1}{|c|}{ River } & $\begin{array}{c}\text { No. of } \\
\text { samples }\end{array}$ & SOD $_{\mathbf{2 0}}$ & $\mathbf{k}$ \\
\hline Blackwater & 1 & 16.3 & 0.046 \\
\hline Axe & 1 & 39.5 & 0.046 \\
\hline Esk & 1 & 14.0 & 0.070 \\
\hline Lod & 1 & 2.9 & 0.186 \\
\hline Lugg & 2 & $5.9 \pm 3.6$ & $0.026 \pm 0.004$ \\
\hline Ithon & 4 & $11.7 \pm 3.7$ & $0.041 \pm 0.012$ \\
\hline Aran & 8 & $23.7 \pm 20.4$ & $0.042 \pm 0.011$ \\
\hline Rede & 1 & 46.3 & 0.131 \\
\hline Towy & 6 & $23.3 \pm 10.9$ & $0.040 \pm 0.013$ \\
\hline Itchen & 7 & $60.4 \pm 15.0$ & $0.062 \pm 0.018$ \\
\hline Frome & 4 & $57.6 \pm 25.1$ & $0.038 \pm 0.006$ \\
\hline Test & 2 & $18.9 \pm 3.6$ & $0.037 \pm 0.001$ \\
\hline
\end{tabular}

Table 3 


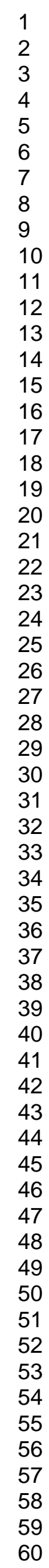


1

2

3

4

5

6

7

8

9

10

11

12

13

14

15

16

17

18

19

20

21

22

23

24

25

26

27

28

29

30

31

32

33

34

35

36

37

38

39

40

41

42

43

44

45

46

47

48

49

50

51

52

53

54

55

56

57

58

59

60
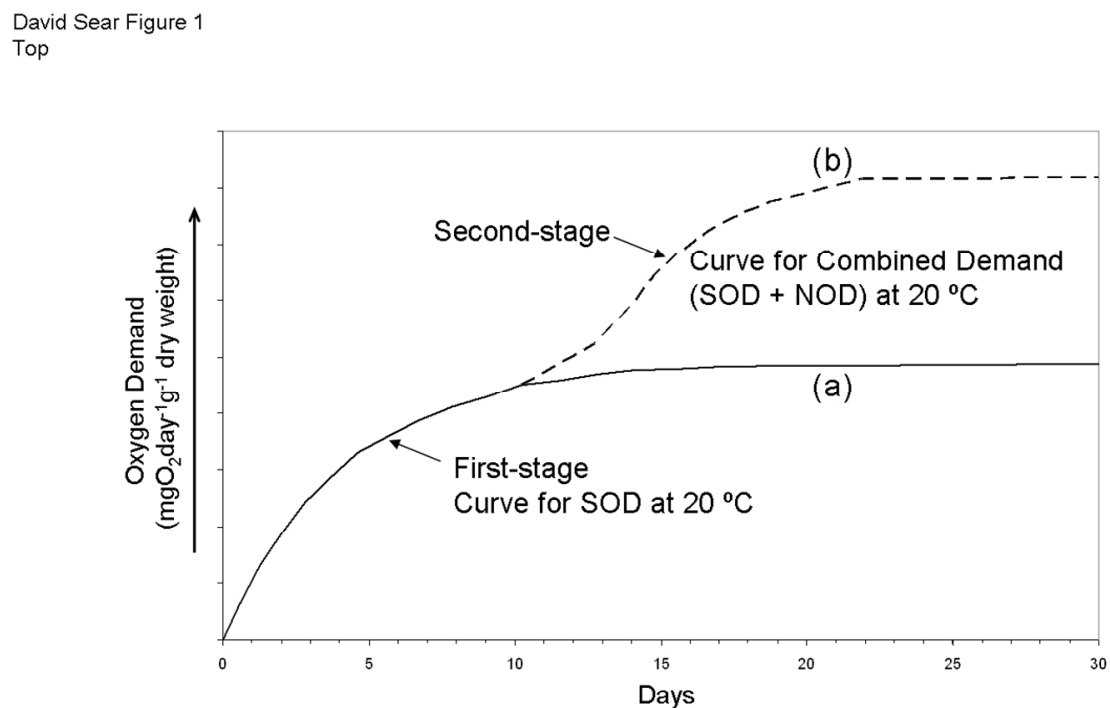

Theoretical graph showing how Sediment Oxygen Demand (SOD) of sediment changes over time in a standard 30 day test at $20^{\circ} \mathrm{C}$.

$254 \times 190 \mathrm{~mm}(150 \times 150 \mathrm{DPI})$ 
David Sear Figure 2

Top

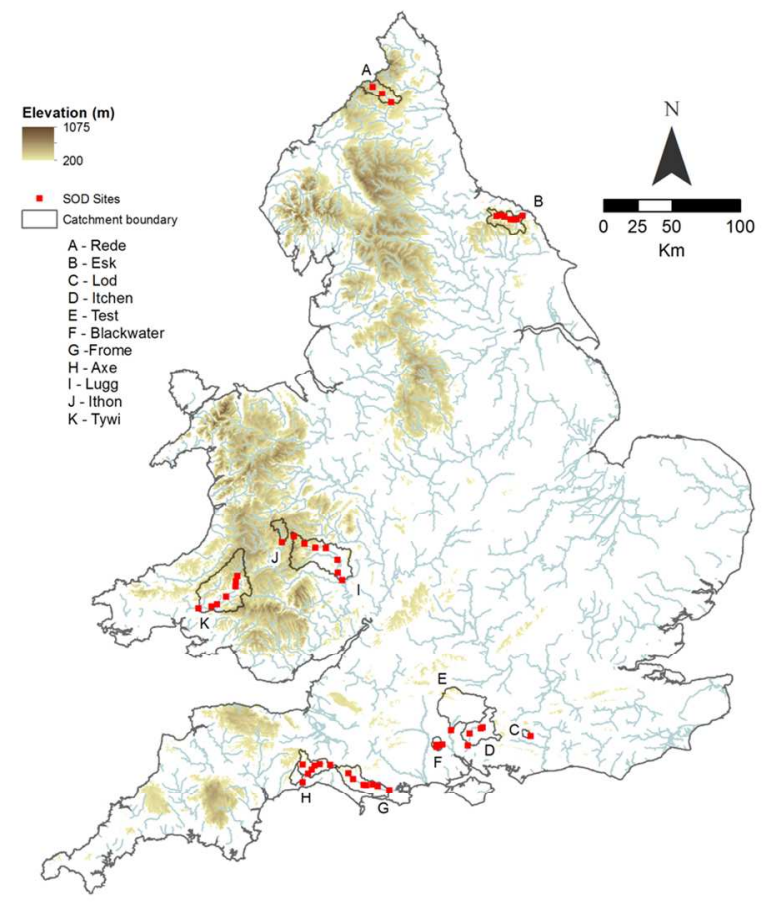

Location of study sites and catchments. Sites cover a range of salmon rives types, from lowland, chalk groundwater dominated gravel rivers to headwater gravel-cobble bed streams in upland catchments draining impermeable igneous geology.

$254 \times 190 \mathrm{~mm}(150 \times 150 \mathrm{DPI})$ 
b
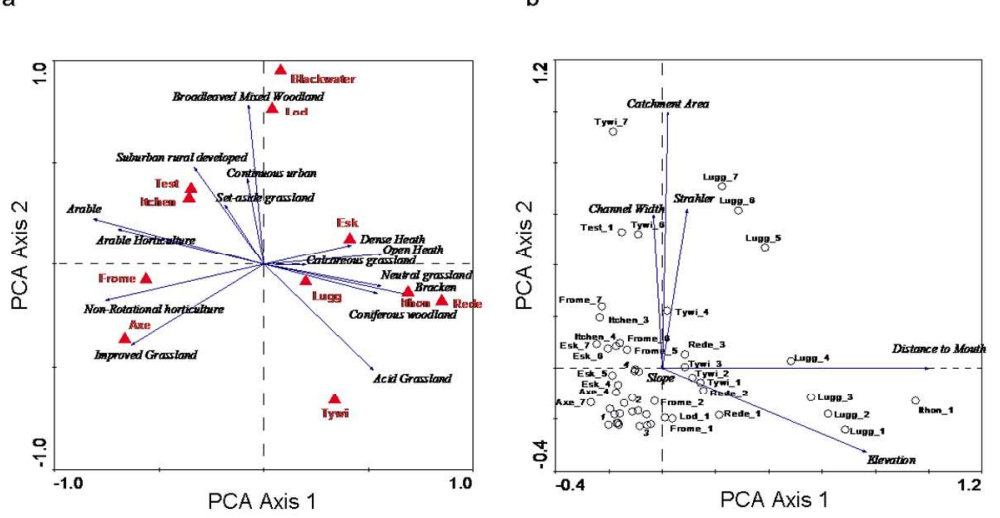

$1=$ Axe_5, Axe_6, Blackw_1, Blackw_2, Blackw_3, Blackw_4, Blackw_5, Blackw_6 $2=$ Axe_2, Axe_3, Esk_1, Esk_3, Itchen_1 $3=$ Axe_1, Esk_2, Tywi_5 4 = Frome_3, Frome_4, Itchen_2 characteristics of field sites used (sites shown as $\circ$ ).

$254 \times 190 m m(150 \times 150$ DPI $)$ 
David Sear Figure 3 Top

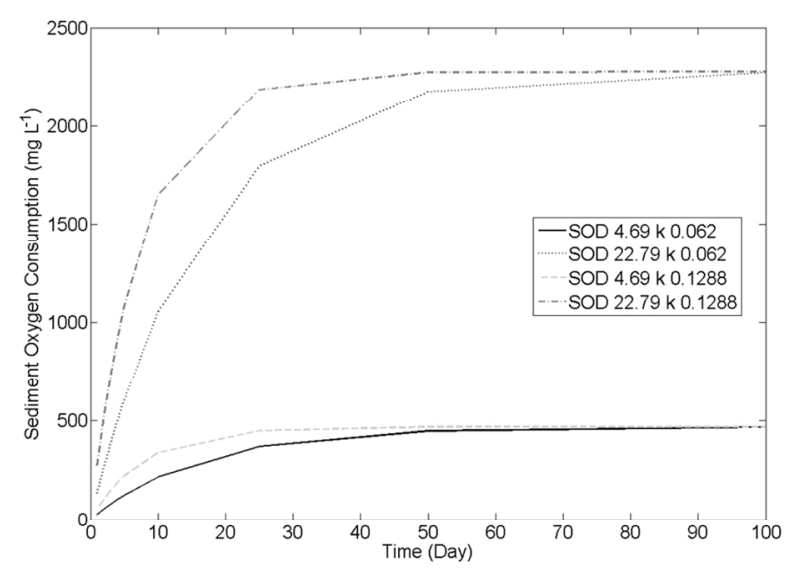

Sensitivity of Sediment Oxygen Consumption (SOC) to SOD and k coefficients.

$254 \times 190 \mathrm{~mm}(150 \times 150 \mathrm{DPI})$ 
David Sear Figure 4 Top

\begin{abstract}
Variation in SOD20 and SOD5 across the study catchments. Itchen, Frome and Test are all groundwater dominated rivers with high instream biomass. Blackwater is a semi-natural woodland stream. The Lod represents only one sample.
\end{abstract}

$254 \times 190 \mathrm{~mm}(150 \times 150 \mathrm{DPI})$ 

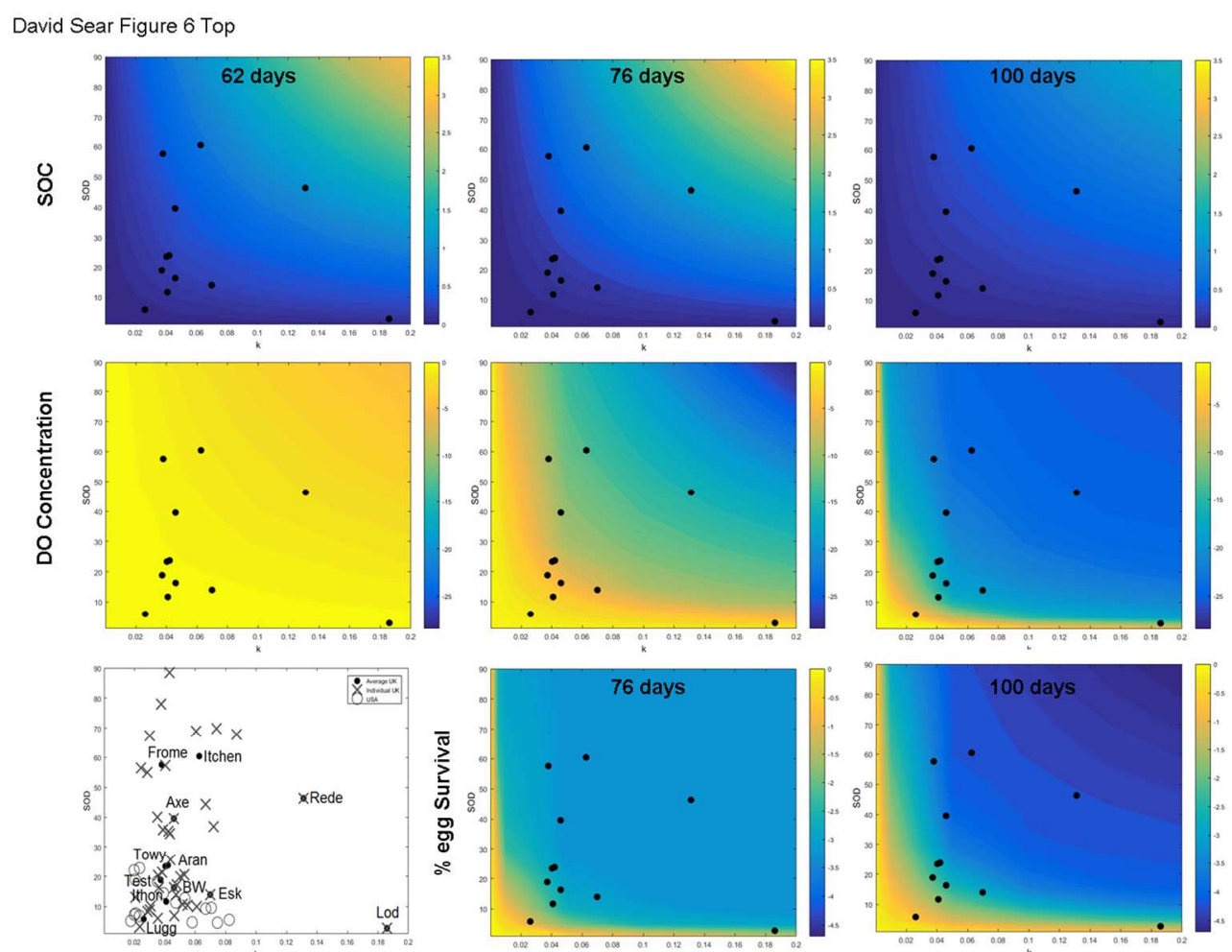

Sensitivity analysis of a) SOC; b) DO; and c) \% egg survival to different SOD and de-oxygenation rates, at different times within the SIDO-UK model River Ithon simulation.

$257 \times 199 \mathrm{~mm}(150 \times 150 \mathrm{DPI})$ 

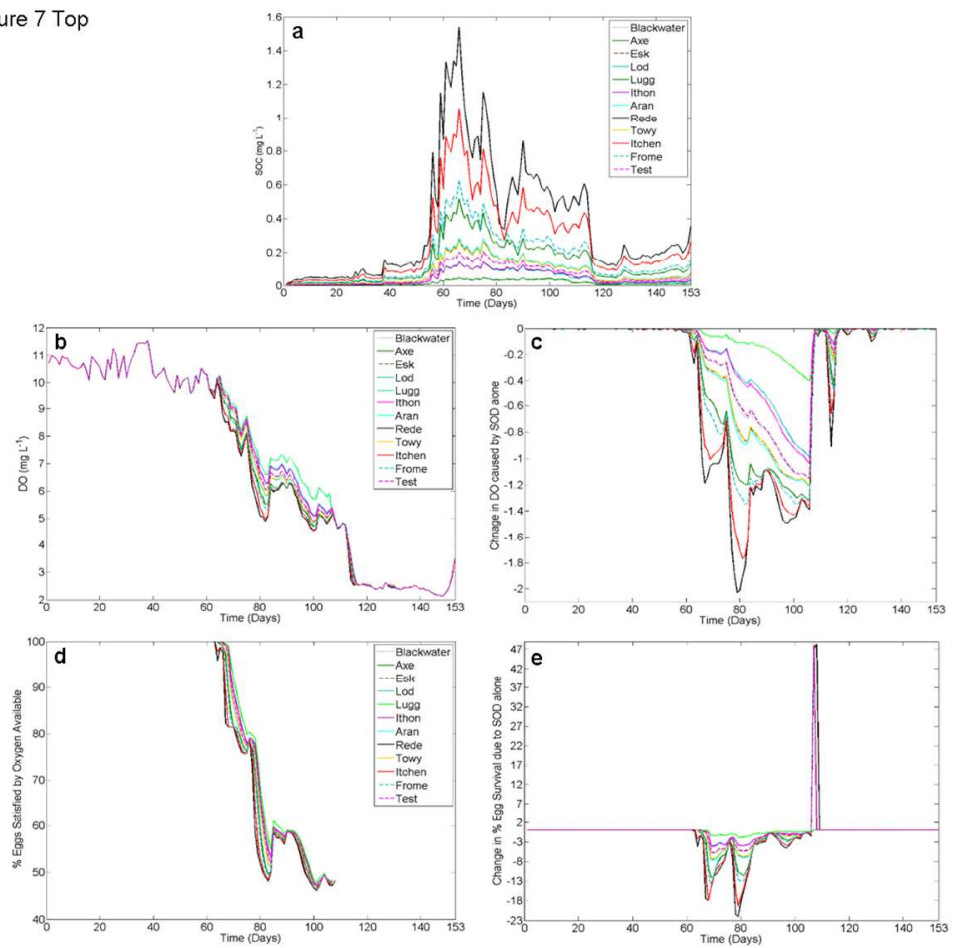

Time series of a) SOC b) absolute DO; c) DO reduction caused by SOC alone; d) egg survival; and e) change in egg survival caused by SOC alone; for a range of different river types sampled in this study.

$254 \times 190 \mathrm{~mm}(150 \times 150 \mathrm{DPI})$ 
Results of Redundancy Analysis (RDA) showing that catchment land use cover is significantly associated with variation in sediment characteristics, with contours of a) SOD5 and b) SOD20 of sediment samples. Sample sites shown as $(0)$.

$254 \times 191 \mathrm{~mm}(150 \times 150$ DPI $)$ 